\title{
Měkkýší fauna (Gastropoda, Bivalvia) z lokality Mušlov (vídeňská pánev)
}

\author{
Mollusc fauna (Gastropoda, Bivalvia) from locality Mušlov (Vienna Basin)
}

Tomáš Turek $\square$, Šárka Hladilová

Ústav geologických věd, Př́rodovědecká fakulta, Masarykova univerzita, Kotlářská 2, 61137 Brno

Key words:

Vienna Basin, Neogene, Badenian,

Mušlov, Mollusca, paleontology

凸 tomasturek159@email.cz

Editor:

Pavla Tomanová Petrová

\begin{abstract}
The Mušlov locality is situated $3.5 \mathrm{~km}$ ESE from the town of Mikulov and it is a part of the Vienna Basin. On the locality a profile rich in shallow-water middle Miocene (Badenian) fauna was uncovered. Its substantial part was deposited in fine-grained calcareous sand, to a lesser extent the fauna also occurred in pebbles and blocks of gray algal limestones. Mainly stone cores with calcareous and degrading shells were found in the limestones, while in the calcareous sands the fossils were well preserved. A rich set of small fauna from fine-grained sand was obtained by washing of samples. There have been determined 73 species of Gastropoda and 25 species of Bivalvia. The most abundant species of gastropods are Tricolia eichwaldi, Rissoina podolica, Bittium reticulatum, Gibbula aff. umbilicalis, Jujubinus striatus, Neritina picta and Turritella bicarinata. Among bivalves the most abundand species are Cardites partschi partschi and Linga columbella. Quantity and degree of conservation of fauna indicate minimal transport and slow sedimentation on the sea floor. Based on the found species, the fauna was mainly bound to a fine-grained substrate but there were also species that preferred the solid substrate. The abundant occurrence living on algal species is evidenced by their rich stands. The fauna lived in the shallow sea with a good oxygenation and a normal salinity. The occurrence of some species documents a warm sea between $20-28{ }^{\circ} \mathrm{C}$.
\end{abstract}

Úvod

Studovaná lokalita geologicky náleží k vídeňské pánvi a v dnešní době je součástí Chráněné krajinné oblasti Pálava. Je tvořena rozsáhlou pískovnou založenou v neogenních a pleistocenních sedimentech. Pískovna leží $3,5 \mathrm{~km}$ vjv. od Mikulova a $1,8 \mathrm{~km}$ sz. od kostela v Sedleci u Mikulova (obr. 1) a v nedávné době byla částečně rekultivována. Jihovýchodní část pískovny je ponechána jako geologický profil. Sedimenty vyskytující se v této pískovně (obr. 2) jsou reprezentovány převážně písky a štěrky, v některých částech pískovny vystupují na povrch valouny a bloky řasových vápenců. $V$ píscích a řasových vápencích se hojně vyskytuje fosilní mořská fauna. První, kdo se zabýval touto lokalitou, byl Hörnes (1870), který uvedl Mušlov jako jedno z nalezišt měkkýšů vídeňské pánve a popsal odtud 17 druhů mlžů. První samostatný článek pojednávající o lokalitě publikoval Jüttner (1933), který z ní popsal štěrky a písky s přeplavenou miocenní faunou. Procházková (1981) nalezla v horních partiích pískovny doklady o redepozici badenské fauny do pleistocenních sedimentů a uvedla $\mathrm{z}$ nich několik zástupců pleistocenních gastropodů. V poslední době byla lokalita zpracována např. Hrabovským (2009), který determinoval druhy červených řas v řasových 


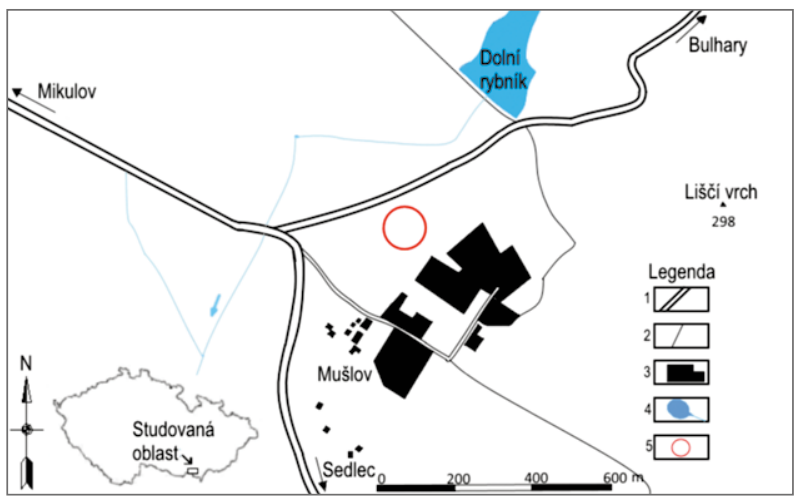

Obr. 1:Pozicestudovanélokality Mušlov.Legenda:1-komunikace; 2-cesta;3-obydlenáplocha;4-vodníplocha;5-studovanálokalita. Fig. 1: Position of the studied locality Mušlov. Legend: 1 - road; 2 - path; 3 - inhabited area; 4 - water area; 5 - studied locality.

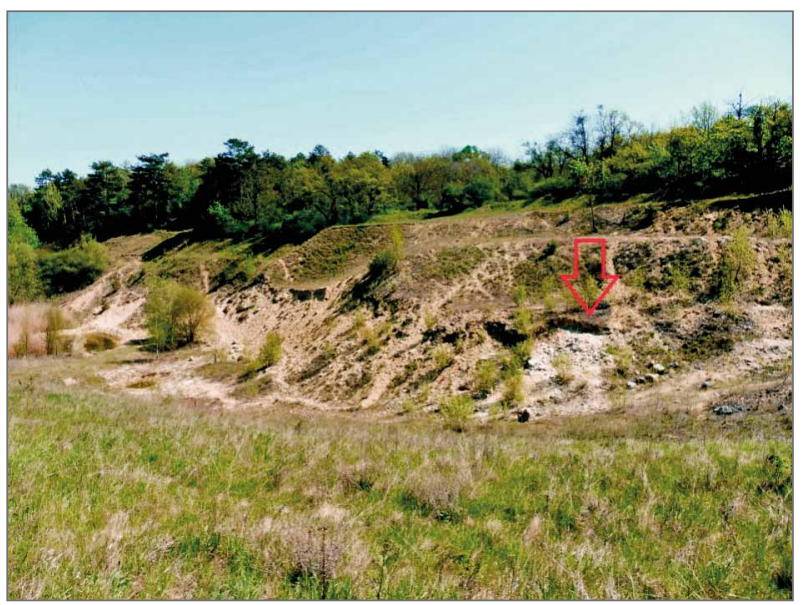

Obr. 2: Pohled na pískovnu Mušlov z j. strany s pozicí studovaného profilu.

Fig. 2: A view of the sand pit Mušlov from the south with position of the studied profile.

vápencích nebo Osvaldovou (2011) a Turkem (2016), kteří se zabývali převážně měkkýší faunou. Lokalita byla součástí exkurzních lokalit na mezinárodní konferenci Molasse Meeting 2016 (Tomanová Petrová, Turek 2016).

\section{Metodika}

V jihozápadní části mušlovské pískovny

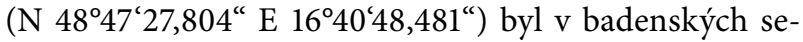
dimentech odkryt geologický profil o rozměrech $210 \times$ $120 \times 110 \mathrm{~cm}$ (obr. 3). Profil byl vytvořen v jemnozrnných vápnitých píscích převážně žluté až hnědožluté barvy a šedých řasových vápencích. Převážná část makrofauny byla získána $\mathrm{z}$ výplavu jemnozrnného vápnitého písku z vrstev 2 a 4 . Plavení bylo provedeno na sítech o rozměrech $5 \mathrm{~mm}$, $2 \mathrm{~mm}$ a $0,5 \mathrm{~mm}$. Ve vrstvách 1 a 3 byly vzorky makrofauny získány $\mathrm{z}$ šedých řasových vápenců. Většina exemplárù byla dobře zachována, proto se daly určit do rodů a většina i do druhů. K systematickému určení byly použity převážně práce Baluka $(1975,1995,1997,2003,2006)$.

\section{Popis zkoumaného profilu}

Vrstva 1 (průměrná mocnost $90 \mathrm{~cm}$ ) je tvořena především šedými až šedožlutými valouny řasových vápenců

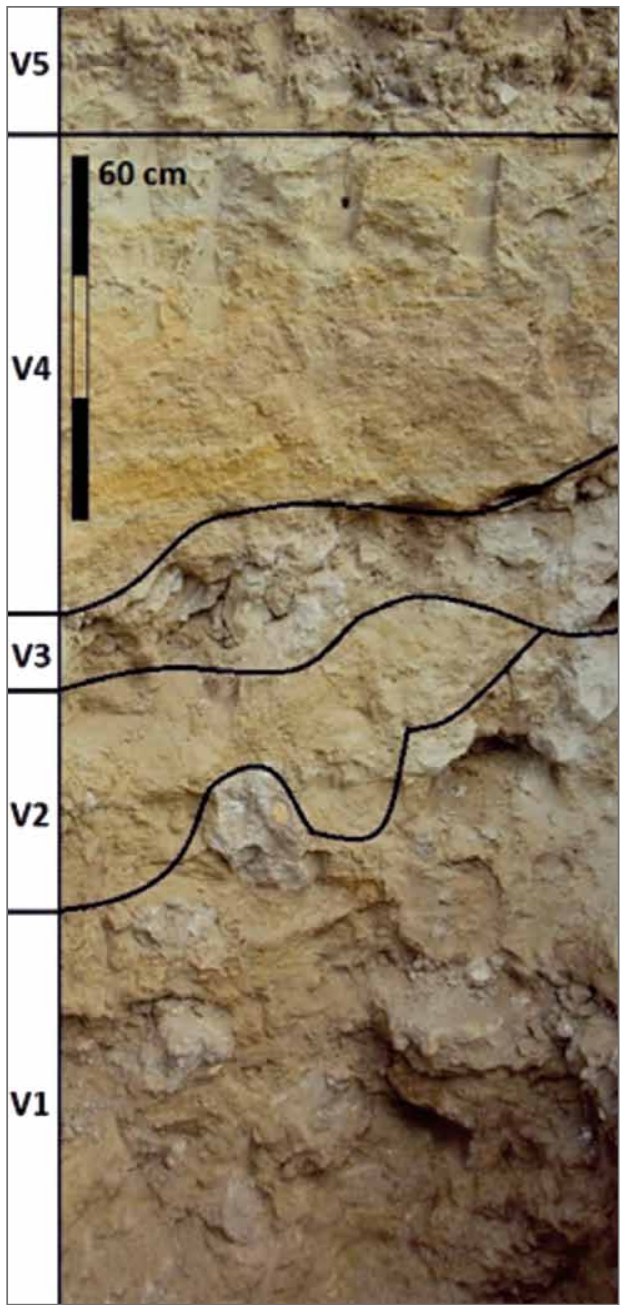

Obr. 3: Profil výkopu na lokalitě Mušlov. Legenda: V1 - valouny a bloky vápence s polohami vápnitého písku; V2 - vápnitý písek; V3 - valouny vápence s polohami vápnitého písku; V4 - vápnitý písek; V5 - osyp.

Fig. 3: Profile of the excavation at the locality Mušlov. Legend: V1 - boulders and blocks of limestones with positions of calcareous sand; V2 - calcareous sand; V3 - boulders and blocks of limestones with positions of calcareous sand; V4 - calcareous sand; V5 - talus.

(do $50 \mathrm{~cm}$ ) s drobnými polohami (do $1 \mathrm{~cm}$ ) jemnozrnného žlutohnědého vápnitého písku s neurčitelnými fragmenty fauny. Na bázi profilu jsou valouny vápenců větší, silně navětralé, směrem do nadloží se zmenšují, ale jsou pevnější. Ve vápencích byla nalezena druhově chudá fauna s převažujícími mlži, préedevším (pod)druhy Glycymeris pilosa deshayesi a Panopea menardi. Z třídy plžů převládá druh Conus sp. Většina jedinců nalezených v této vrstvě byla zachována ve formě kamenných jader s ojedinělými pozůstatky původních schránek na povrchu.

Vrstva 2 je tvořena jemnozrnným vápnitým pískem žlutohnědé barvy, který obsahuje malé úlomky (do $5 \mathrm{~cm}$ ) šedých řasových vápenců. Tato vrstva má proměnlivou mocnost od $20 \mathrm{~cm}$ až po úplné vyklínění na pravé straně profilu. $\mathrm{V}$ tomto sedimentu byla nalezena bohatá makrofauna. Mezi nejhojnější zástupce plžů patří Turritella bicarinata, Tricolia eichwaldi, Bittium reticulatum, Gibbula aff. umbilicalis, Jujubinus striatus, Neritina picta a Rissoina 
Tab. 1: Nalezené druhy měkkýšů z lokality Mušlov.

Tab. 1: Found species of mollusc from the locality Mušlov.

Třída Gastropoda

\begin{tabular}{|c|c|c|c|}
\hline Čeled' & Druh & Počet & Vrstva \\
\hline \multirow[t]{7}{*}{ Rissoidae (Gray, 1847) } & Alvania (Alvania) perregularis (Sacco, 1895) & 12 & 4 \\
\hline & Alvania (Alvania) ampulla (Eichwald, 1853) & 61 & 4,2 \\
\hline & Rissoina (Rissoina) podolica Cossmann, 1921 & 129 & 4,2 \\
\hline & Rissoina (Phosinella) steinabrunnensis (Sacco, 1895) & 3 & 4 \\
\hline & Rissoina sp. & 3 & 4 \\
\hline & Mohrensternia cf. inflata (Hörnes, 1856) & 2 & 4 \\
\hline & Manzonia cf. miocrassicosta (Sacco, 1895) & 2 & 4 \\
\hline Caecidae (Gray, 1850) & Caecum cf. tenuicostulatum (de Folin, 1881) & 4 & 4 \\
\hline Calyptraeidae (Lamarck, 1809) & Crepidula (Janacus) crepidula (Linnaeus, 1767) & 1 & 4 \\
\hline Triviidae (Troschel, 1863) & Trivia aff. europaea (Montagu, 1808) & 2 & 4 \\
\hline Cypraeidae (Rafinesque, 1815) & Zonaria dertamygdaloides (Sacco, 1894) & 1 & 4 \\
\hline Naticidae (Guilding, 1834) & Euspira helicina (Brocchi, 1814) & 28 & 4,2 \\
\hline \multirow{2}{*}{ Vermetidae (d’Orbigny, 1840) } & Petaloconchus intortus (Lamarck, 1818) & 24 & 4 \\
\hline & Lemintina arenaria (Linnaeus, 1766) & 31 & 4 \\
\hline \multirow[t]{6}{*}{ Cerithiidae (Fleming, 1828) } & Bittium (Bittium) reticulatum (da Costa, 1779) & 103 & 4,2 \\
\hline & Bittium spina (Partsch, 1856) & 7 & 4 \\
\hline & Cerithium (Thericium) vulgatum europaeum (Mayer, 1878) & 48 & 4,2 \\
\hline & Cerithium vulgatum miospinosum (Sacco, 1895) & 2 & 4 \\
\hline & Cerithium bronni (Partsch in Hörnes, 1845) & 26 & 4,2 \\
\hline & Cerithium zeuschneri (Pusch, 1837) & 7 & 4,2 \\
\hline \multirow[t]{4}{*}{ Turritellidae (Lovén, 1847) } & Turritella spirata (Brocchi, 1814) & 23 & 5,4 \\
\hline & Turritella bicarinata (Eichwald, 1830) & 311 & $5,4,3,2,1$ \\
\hline & Turritella vermicularis tricincta (Borson, 1812) & 1 & 5 \\
\hline & Turritella sp. (Lamarck, 1799) & 1 & 4 \\
\hline \multirow[t]{2}{*}{ Litiopidae (Gray, 1847) } & Alaba elata (Boettger, 1901) & 1 & 4 \\
\hline & Alaba costellata anomala (Eichwald, 1850) & 3 & 4 \\
\hline \multirow[t]{3}{*}{ Cerithiopsidae (H. Adams a A. Adams, 1854) } & Seila (Seila) trilineata (Philippi, 1836) & 1 & 4 \\
\hline & Cerithiopsis sp. (Forbes a Hanley, 1850) & 2 & 4 \\
\hline & Cerithiopsis (Dizioniopsis) cf. bilineata (Hörnes, 1856) & 1 & 4 \\
\hline Triphoridae (Gray, 1847) & Monophorus cf. perversus (Linnaeus, 1758) & 1 & 4 \\
\hline Epitoniidae (Berry, 1910) & Cirsotrema dalli (Rehder, 1945) & 1 & 4 \\
\hline Muricidae (Fleming, 1828) & Hadriania sp. (Bucquoy a Dautzenberg, 1882) & 1 & 4 \\
\hline \multirow[t]{2}{*}{ Olividae (Latreille, 1825) } & Oliva (Neocylindrus) dufresnei (Basterot, 1825) & 4 & 4 \\
\hline & Ancilla (Baryspira) glandiformis (Lamarck, 1810) & 20 & 4,2 \\
\hline \multirow[t]{4}{*}{ Mitridae (Swainson, 1931) } & Mitraria (Mitraria) goniophora (Bellardi, 1850) & 1 & 4 \\
\hline & Vexillum ebenus (Lamarck, 1811) & 4 & 4 \\
\hline & Vexillum (Costellaria) cf. pseudorecticosta (Boettger, 1901) & 1 & 4 \\
\hline & Vexillum sp. (Röding, 1798) & 2 & 4 \\
\hline \multirow[t]{8}{*}{ Conidae (Fleming, 1822) } & Lautoconus ponderosus (Brocchi, 1814) & 1 & 2 \\
\hline & Conilithes exaltatus (Eichwald, 1830) & 8 & 4,2 \\
\hline & Conus (Lautoconus) posticestriatus Kojumdgieva, 1960 & 5 & 4 \\
\hline & Conilithes cf. brezinae (Hoernes a Auinger, 1879) & 4 & 4 \\
\hline & Lautoconus cf. steinabrunnensis (Sacco, 1893) & 4 & 4,2 \\
\hline & Kalloconus berghausi (Michelotti, 1847) & 1 & 4 \\
\hline & Conus sp. 1 (Linnaeus, 1758) & 1 & 4 \\
\hline & Conus sp. 2 (Linnaeus, 1758) & 2 & 3 \\
\hline \multirow[t]{4}{*}{ Turridae (Swainson, 1840) } & Mangelia vulpecula (Brocchi, 1814) & 1 & 4 \\
\hline & Cythara (Mangelia) contracta (Bellardi, 1877) & 1 & 4 \\
\hline & Cythara sp. (Schumacher, 1817) & 2 & 4 \\
\hline & Philbertia sp. (Monterosato, 1884) & 1 & 4 \\
\hline Mangeliidae (Fischer, 1883) & Gibberulina philippi (Monterosato, 1878) & 5 & 4 \\
\hline Nassariidae (Iredale, 1835) & Hinia colorata vindobonensis (Mayer, 1856) & 27 & 4,2 \\
\hline \multirow[t]{2}{*}{ Fasciolariidae (Gray, 1853) } & Fusus valenciennesi (Grateloup, 1840) & 1 & 4 \\
\hline & Euthriofusus sp. (Cossmann, 1901) & 1 & 3 \\
\hline Neritidae (Rafinesque, 1815) & Neritina picta (Férussac, 1825) & 123 & 4,2 \\
\hline Phasianellidae (Swainson, 1840) & Tricolia eichwaldi (Hörnes, 1856) & 214 & 4,2 \\
\hline Cyclostrematidae (Fischer, 1885) & Leucorhynchia rotellaeformis (Grateloup, 1840) & 10 & 4,2 \\
\hline
\end{tabular}


Tř́́da Gastropoda - pokračování

\begin{tabular}{|l|l|r|r|}
\hline Čeled' & Druh & Počet & Vrstva \\
\hline Trochidae (Rafinesque, 1815) & Gibbula biangulata (Eichwald, 1830) & 1 & 4 \\
\hline & Gibbula (Gibbula) buchi (Dubois, 1831) & 4 & 4 \\
\hline & Gibbula sp. (Risso, 1826) & 1 & 4 \\
\hline & Gibbula aff. umbilicalis (da Costa, 1778) & 178 & 4,2 \\
\hline & Jujubinus striatus (Linnaeus, 1758) & 125 & 4,2 \\
\hline Turbinidae (Rafinesque, 1815) & Clanculus araonis (Basterot, 1825) & 3 & 4 \\
\hline & Astraea (Bolma) meynardi (Michelotti, 1847) & 3 & 4,5 \\
\hline & Astraea (Bolma) cf. granosa (Borson, 1821) & 1 & 4 \\
\hline Fissurellidae (Fleming, 1822) & Bolma perangulata (var. spinosa) (Friedberg) & & 4 \\
\hline Pyramidellidae (Gray, 1840) & Diodora italica (Defrance, 1820) & & 21 \\
\hline & Clathrella clathrata (Philippi, 1844) & 2 & 4,2 \\
\hline Retusidae (Thiele, 1925) & Pyramidella plicosa (Bronn, 1838) & & 4 \\
\hline Ringiculidae (Philippi, 1853) & Retusa elongata (Eichwald, 1830) & & 4,2 \\
\hline & Ringicula auriculata (Ménard de la Groye, 1811) & 3 & 4 \\
\hline & Ringicula cf. costata (Eichwald, 1831) & 4 & 4,5 \\
\hline
\end{tabular}

Tř́́da Bivalvia

\begin{tabular}{|c|c|c|c|}
\hline Čeled' & Druh & Počet & Vrstva \\
\hline \multirow[t]{3}{*}{ Arcidae (Fleming, 1828) } & Anadara turonica (Dujardin, 1837) & 35 & 4,2 \\
\hline & Anadara sp. (Gray, 1847) & 1 & 4 \\
\hline & Arca naoe (Linnaeus, 1758) & 1 & 4 \\
\hline Noetiidae (Stewart, 1930) & Striarca lactea (Linnaeus, 1758) & 10 & 4 \\
\hline Glycymerididae (Dall, 1908) & Glycymeris pilosa deshayesi (Mayer, 1868) & 12 & $4,3,2,1$ \\
\hline Spondylidae (Gray 1826) & Spondylus crassicosta (Lamarck, 1819) & 4 & 4 \\
\hline Pectinidae (Lamarck, 1819) & Gigantopecten cf. latissimus (Brocchi, 1814) & 5 & 3 \\
\hline Plicatulidae (Wilson 1930) & Plicatula mytilina (Philippi, 1836) & 11 & 4,2 \\
\hline Pinnidae (Leach, 1819) & Pinna tetragona (Brocchi, 1814) & 1 & 3 \\
\hline \multirow[t]{3}{*}{ Chamidae (Lamarck, 1809) } & Chama gryphoides (Linnaeus, 1758) & 2 & 4 \\
\hline & Chama gryphina (Lamarck, 1819) & 11 & 4 \\
\hline & Pseudochama gryphina (Lamarck, 1819) & 1 & 4 \\
\hline \multirow[t]{5}{*}{ Lucinidae (Fleming, 1828) } & Codakia haidingeri (Hörnes, 1865) & 3 & 4 \\
\hline & Codakia leonina (Basterot, 1825) & 1 & 4 \\
\hline & Gibbolucina transversa (Bronn, 1831) & 2 & 4 \\
\hline & Linga columbella (Lamarck, 1818) & 192 & $5,4,3,2,1$ \\
\hline & Loripes dentatus niveus (Eichwald 1830) & 18 & 4,2 \\
\hline Mesodesmatidae (Gray, 1840) & Ervilia pusilla (Philippi, 1836) & 21 & 4,2 \\
\hline \multirow[t]{4}{*}{ Veneridae (Leach, 1819) } & Venus subrotunda (Defrance, 1828) & 2 & 4 \\
\hline & Circomphalus haidingeri (Hörnes, 1862) & 2 & 4 \\
\hline & Clausinella scalaris (Bronn, 1831) & 1 & 4 \\
\hline & Periglypta sp. (Jukes-Brown, 1914) & 1 & 4 \\
\hline \multirow[t]{2}{*}{ Carditidae (Lamarck, 1809) } & Cardita crassa vindobonensis (Sacco, 1899) & 1 & 2 \\
\hline & Cardites partschi partschi (Goldfuss, 1837) & 258 & $5,4,3,2,1$ \\
\hline Hiatellidae (Gray, 1824) & Panopea menardi (Deshayes, 1828) & 6 & 3,1 \\
\hline Nuculidae (Lamarck, 1799) & Nucula cf. nucleus (Linnaeus, 1758) & 1 & 4 \\
\hline
\end{tabular}

Třída Scaphopoda

\begin{tabular}{|l|l|r|r|}
\hline Čeled' & Druh & Počet & Vrstva \\
\hline Dentaliidae Children 1834 & Fissidentalium badense Partsch, 1856 & 3 & 4 \\
\hline & Dentalium cf. michelotti Hörnes, 1856 & 4 & 4 \\
\hline
\end{tabular}

podolica, z mlžů jsou to Linga columbella a Cardites partschi partschi.

Vrstva 3 (průměrná mocnost $24 \mathrm{~cm}$ ) je tvořena úlomky a valouny šedých řasových vápenců s drobnými polohami žlutohnědých jemnozrnných vápnitých písků. Fauna v něm nalezená je stejná jako ve vrstvě 1 , až na nálezy několika jedinců druhu Macrochlamis nodosiformis a jednoho exempláře druhu Pinna tetragona.
Vrstva 4 (průměrná mocnost $65 \mathrm{~cm}$ ) je tvořena převážně jemnozrnným vápnitým pískem žlutohnědé barvy na bázi s postupným přechodem ke světle šedé ve svrchní části vrstvy. Uprostřed vrstvy se objevuje čočka narůžovělého písku, která na obou stranách profilu vykliňuje. Na bázi vrstvy 4 se v malém množství objevují úlomky šedých řasových vápenců. $\mathrm{V}$ této části se také nacházejí kamenná jádra druhu Conus sp. V celé vrstvě 4 byla nalezena nejbohatší fauna s největším množstvím 

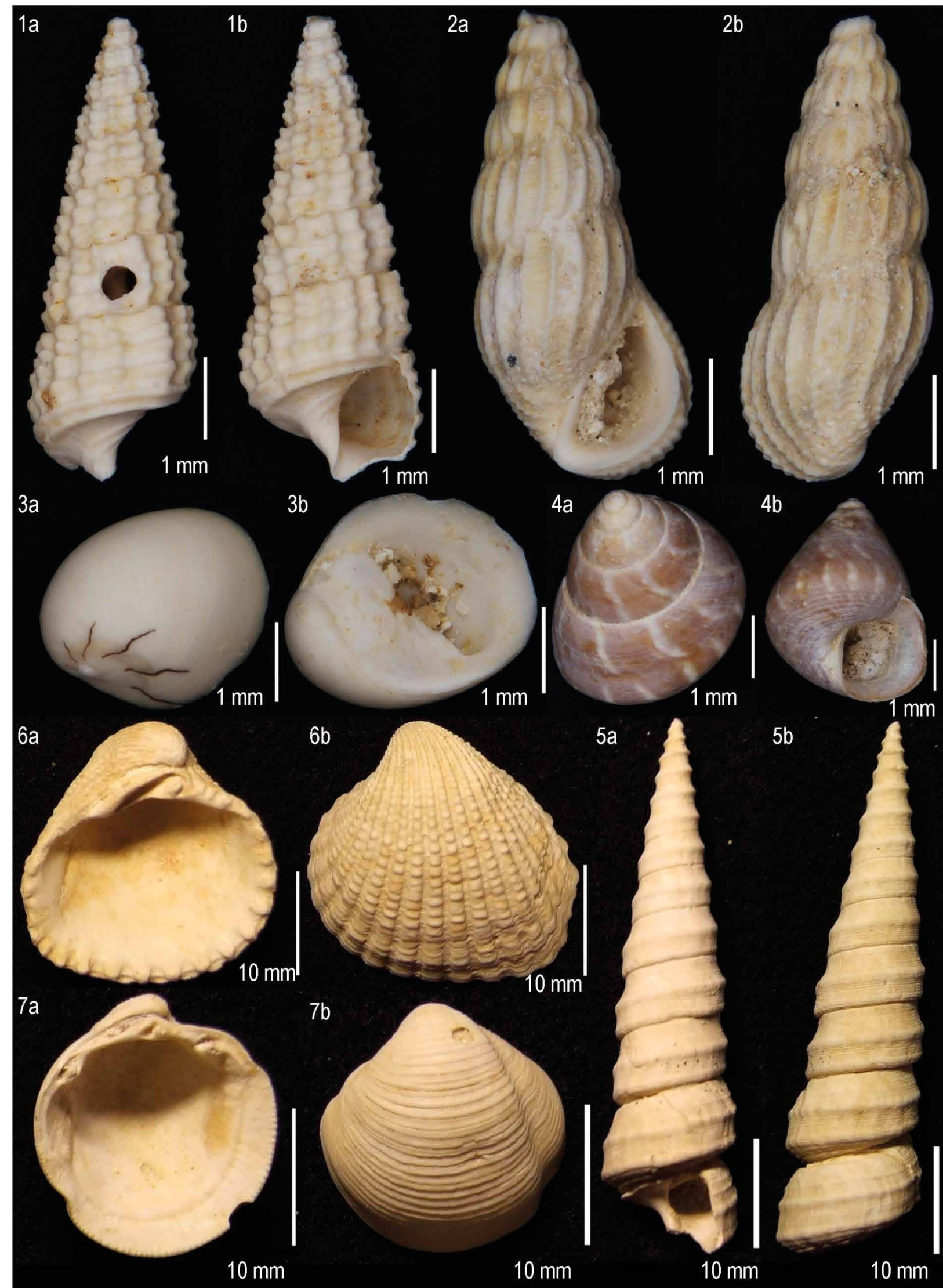

Obr. 4: Nejhojněji nalezené druhy měkkýšů. 1a, b - Bittium (Bittium) reticulatum (da Costa, 1779); 2a, b - Rissoina (Rissoina) podolica Cossmann, 1921, 3a, b - Neritina picta (Férussac, 1825); 4a, b - Jujubinus striatus (Linnaeus, 1758); 5a, b - Turritella bicarinata (Eichwald, 1830); 6a, b - Cardites partschi partschi (Goldfuss, 1837); 7a, b - Linga columbella (Lamarck, 1818).

Fig. 4: The most abundant species of molluscs. 1a, b - Bittium (Bittium) reticulatum (da Costa, 1779); 2a, b - Rissoina (Rissoina) podolica Cossmann, 1921, 3a, b - Neritina picta (Férussac, 1825); 4a, b - Jujubinus striatus (Linnaeus, 1758); 5a, b - Turritella bicarinata (Eichwald, 1830); 6a, b - Cardites partschi partschi (Goldfuss, 1837); 7a, b - Linga columbella (Lamarck, 1818). 
jedinců. Tato fauna je druhově podobná fauně vyskytující se ve vrstvě 2 , jen početnější. $Z$ této vrstvy byly pro tuto lokalitu nově determinovány druhy např. Alvania ( $A l$ vania) perregularis, Rissoina steinabrunnensis, Gibbula biangulata. V této vrstvě bylo zjištěno jisté usměrnění schránek druhu Turritella bicarinata, jejichž vrcholy byly často orientovány sv. směrem.

Vrstva 5 (průměrná mocnost $20 \mathrm{~cm}$ ) je tvořena recentní sutí žlutého jemnozrnného písku s úlomky šedých řasových vápenců. $\mathrm{V}$ písku byla nalezena chudá fauna vyskytující se v ostatních vrstvách, např.: Turritella bicarinata a Cardites partschi partschi.

\section{Nalezená fauna}

Celkem bylo nalezeno 2428 jedinců. Nejpočetněji byl zastoupen kmen Mollusca (tab. 1), a to třídou Gastropoda (73 druhů) s celkovým počtem 1593 jedinců, třídou Bivalvia ( 25 druhů) s celkovým počtem 590 jedinců a 7 jedinců (2 druhy) trrídy Scaphopoda. Dále byl na lokalitě zastoupen kmen Brachiopoda třídou Rhynchonellata s druhem Terebratula sp. a kmen Cnidaria, reprezentovaný třídou Anthozoa s druhy Porites leptoclada, Sideastrea fröhlichiana a Cladocora depauperata. Z obratlovců byl zjištěn kmen Chordata, který byl zastoupen třídou Actinopterygii s druhy Pagrus cinctus, Diplodus sitifensis a aff. Pelagus sp. a třídou Chondrichthyes s druhy Aetobatus arcuatus, Myliobatis sp. a Taeniurops aff. cavernosus. Ve výplavu bylo také nalezeno několik exemplářủ blíže nedeterminovaných druhů mechovek, klepítek korýšů, serpulidních červů a ostny a destičky ostnokožců.

Mezi nejhojnější nalezené druhy plžů (obr. 4) patř́ Tricolia eichwaldi, Rissoina podolica, Bittium reticulatum, Gibbula aff. umbilicalis, Jujubinus striatus, Neritina picta a Turritella bicarinata. Z mlžů jsou to Cardites partschi partschi a Linga columbella. $\mathrm{Na}$ základě litologie sedimentů je lokalita řazena do svrchního badenu (hrušeckého souvrství), ke kterému lze nalezenou faunu měkkýšů přiřadit. Největší množství nalezené fauny pochází $z$ vrstvy 2 a 4 . Většina menších jedinců $\mathrm{z}$ těchto vrstev nenesla známky výraznějšího poškození. U větších schránek plžů byly nejčastěji poškozeny vrcholové části spiry a ústí, u mlžủ byly misky rozlámány na více částí.

\section{Tafonomické zpracování nalezené fauny}

V profilu bylo možno rozlišit dvě tafofacie s různým typem zachování fosílií. První tafofacie je tvořena vápenci, ve kterých se nalézají především kamenná jádra se zvápenatělými a rozpadavými schránkami převážně čeledi Conidae a poddruhu Glycymeris pilosa deshayesi. U mlžů se nejčastěji vyskytují kamenná jádra obou misek pohromadě, a nemohlo tedy dojít po smrti k transportu. Druhá tafofacie je tvořena vápnitými písky s bohatou fosilní faunou, která je velmi dobře zachována. Nalezení jedinci v této tafofacii mají původní schránku a nejsou výrazně ováleni. U mlžů byly většinou nalezeny oddělené misky, ale $\mathrm{v}$ několika prrípadech se podařilo najít i misky dosud spojené. Část schránek mlžů poddruhu Glycymeris pilosa deshayesi byla fragmentární, ale fragmenty se nalézaly v téže vrstvě a schránku bylo možno zrekonstruovat. Vzhledem k nálezové situaci lze předpokládat, že schránky pravděpodobně neprodělaly delší transport.

Na některých schránkách plžů i mlžů se vyskytují stopy predace Oichnus paraboloides způsobené převážně zástupci gastropodů Muricidae a Naticidae (Výmolová 2012). Na schránce mlže Cardita crassa vindobonensis nalezené ve vápnitém písku byly zjištěny stopy ichnorodu Entobia. Napadena byla pouze část schránky nad sedimentem. $Z$ toho můžeme usuzovat, že schránka byla po smrti částečně pohřbena a následně napadena.

Na povrchu schránky jedince Glycymeris pilosa deshayesi a uvnitř jedné misky druhu Cardites partschi partschi byl nalezen přisedlý serpulidní červ. Nález serpulidního červa uvnitř misky dokládá, že došlo k jeho přisednutí až po uhynutí mlže, což svědčí o pomalé sedimentaci a nízké dynamice vodního prostředí.

Schránky druhu Vexillum ebenus a Neritina picta mají částečně zachované původní zbarvení.

\section{Paleoekologie}

K fauně vázané na jemnozrnné vápnité písky můžeme přiřadit hojný druh Turritella bicarinata, který převážně žije na jílovitém až písčitém podkladu (Latal et al. 2006). Nálezy zástupců čeledi Conidae také ukazují na nezpevněný jílovitý, popř. jemně písčitý substrát (Chira, Voia 2001; Harzhauser, Landau 2016). Hojné druhy Alvania (Alvania) ampulla a Alvania (Alvania) perregularis vyhledávají ke svému životu převážně jílovitý nebo jemně písčitý sediment s porosty řas (Mandic et al. 2002; Kowalke, Harzhauser 2004). Na bohaté porosty řas také ukazuje velmi hojný druh Bittium reticulatum žijící do hloubky $15 \mathrm{~m}$ na jemnozrnném substrátu (Høisæter 2009), poprŕípadě druhy Tricolia (Tricolia) eichwaldi a Gibbula sp. (Zuschin et al. 2007). Porosty řas také dokládají velmi dobré prosvětlení a prokysličení povrchu dna nad sedimentem. Na pevný substrát můžeme usuzovat na základě prrítomnosti druhu Diodora italica, který vyhledává převážně kamenité podloží (Russo 2017). Toto prostředí také indikují nálezy korálů.

Hojný výskyt druhů Alvania (Alvania) ampulla a Alvania (Alvania) perregularis žijících převážně v mělčím litorálu dokládá mělkovodní prostředí (Kowalke, Harzhauser 2004). Druh Petaloconchus intortus žije často v mělké subtidální zóně (Pisera 1985). Druh Diodora italica je v recentu vázán převážně na hloubky od 10-60 m (Russo 2017). V podobné hloubce žije také druh Pseudochama gryphina (Meric et al. 2010). Převážně v mělkých vodách jsou rozšířeni zástupci čeledi Conidae, kteří jsou na lokalitě zastoupeni větším množstvím druhů (Chira, Voia 2001; Harzhauser, Landau 2016). Mělké moře také potvrzují druhy Euspira helicina a Turritella (Zaria) spirata, popř́padě i druh Turritella bicarinata žijící v infralitorálu či mělčím cirkalitorálním pásmu (Seitl 1981).

Druhy Alvania (Alvania) ampulla a Alvania (Alvania) perregularis žijí v mořích s normální salinitou (Kowalke, Harzhauser 2004). Normální salinitu potvrzuje i velmi hojný druh Turritella bicarinata (Latal et al. 2006), př́padně druh Euspira helicina, resp. druh Turritella 
(Zaria) spirata, kterýje Seitlem (1981) považován za přísně stenohalinní. To prokazuje i výskyt druhu Pseudochama gryphina, který žije ve vodách o minimální salinitě $30 \%$ (Meric et al. 2010).

Na lokalitě bylo nalezeno větší množství eurytermních druhů, například Bittium reticulatum žijící dnes jak ve Středozemním moři, tak i v severním Atlantiku (Høisæter 2009). Na teplejší prostředí však můžeme usuzovat na základě výskytu čeledi Conidae, která je na lokalitě zastoupena velkým množstvím druhů, které nežijí ve vodě chladnější než $20^{\circ} \mathrm{C}$ (Chira, Voia 2001). Teplé prostředí rovněž dokládá druh Petaloconchus intortus, který v dnešní době žije v teplých vodách (Pisera 1985), popřípadě Plicatula mytilina žijící v tropických mělkých vodách (Garilli 2011). Druhy Glycymeris sp., Cardites partschi partschi a Panopea meynardi podle Rundice et al. (2013) značí vyšší teploty, které v létě mohly dosahovat až k $28^{\circ} \mathrm{C}$.

\section{Diskuze}

Na lokalitě Mušlov je doložena i přítomnost pleistocenní fauny $\mathrm{v}$ sedimentech $\mathrm{s}$ faunou badenskou. To někteří autoři (Procházková 1981; Osvaldová 2011) přisuzují přeplavení badenských sedimentů během pleistocénu a usazení spolu s pleistocenní faunou. V námi studovaném profilu se však nepodařilo najít žádný doklad o prítomnosti pleistocenní fauny. Ve vápnitém písku byla nalezena druhově bohatá, nevytříděná a dobře zachovaná fauna včetně mlžů s oběma miskami, které by se při transportu oddělily. Soudíme proto, že sedimenty zachycené ve studovaném profilu nebyly redeponovány.

V profilu byly také nalezeny valouny vápence, které byly uloženy ve vrstvách vápnitého písku. Jelikož sediment, ve kterém byly nalezeny, nenese známky pozdější redepozice, lze soudit, že tyto vápence se do vápnitého písku dostaly již během sedimentace ve svrchním badenu a fauna v nich nalezená je vzhledem k sedimentaci starší, ale také nejspíše svrchnobadenského stáří.
Osvaldová (2011) se přiklání k názoru, že fauna $z$ Mušlova je nápadně podobná fauně $z$ Kienbergu. Nálezy z nového profilu však nenesou známky redepozice a fauna $\mathrm{v}$ něm nalezená se od fauny nalezené na Kienbergu částečně liší ve složení měkkýších společenstev.

\section{Závěr}

V jihovýchodní části pískovny v Mušlově byl odkryt profil v sedimentech svrchního badenu, ze kterého bylo získáno značné množství fauny. Celkem se podařilo nalézt 2428 jedinců měkkýšů tříd Bivalvia, Gastropoda a Scaphopoda. Z plžů bylo určeno 73 druhů, z nichž nejhojnější byli Turritella bicarinata, Tricolia eichwaldi, Bittium reticulatum, Gibbula aff. umbilicalis, Jujubinus striatus, Neritina picta a Rissoina podolica. Z mlžů se podařilo determinovat 25 druhů s převahou taxonů Linga columbella a Cardites partschi partschi. Dále byli nalezeni zástupci ramenonožců, mechovek, červů, žahavců, členovců, ostnokožců a strunatců.

Značná část fosilií získaných z výplavu jemnozrnného vápnitého písku $z$ vrstev 2 a 4 nenese stopy poškození, je velmi dobře zachovaná a bez známek vytřídění. Z řasových vápenců vrstvy 1 a 3 byla získána především poškozená fauna $v$ podobě kamenných jader s ojedinělými pozůstatky původní schránky na povrchu.

$\mathrm{Na}$ základě paleoekologických požadavků nalezených druhů předpokládáme, že zdejší moře bylo mělké, klidné a dobře prokysličené. Fauna žila převážně na nezpevněném, písčitém sedimentu. Nalezené druhy měkkýšů a výskyt korálů dokládají teplé moře. Rybí asociace $s$ rejnoky se vyskytovala $v$ blízkosti podmořských útesů. Vzhledem k nalezeným skupinám živočichů lze usuzovat, že mořské prostředí bylo značně diverzifikované a žilo zde mnoho druhů organizmů.

\section{Poděkování}

Předložené výsledky byly získány v rámci Specifického výzkumu ÚGV MU (1363). Autoři by rádi poděkovali recenzentům a také pracovníkům redakce za přpomínky, které vedly ke zkvalitnění textu. 


\section{Literatura}

Baluk, W. (1975). Lower Tortonian Gastropods from Korytnica, Poland, Part I. - Paleontologia Polonica, 32, 1, 1-234.

Baluk, W. (1995). Middle Miocene (Badenian) gastropods from Korytnica, Poland, Part II. - Acta Geologica Polonica, 45, 3-4, 153-332.

Baluk, W. (1997). Middle Miocene (Badenian) gastropods from Korytnica, Poland, Part III. - Acta Geologica Polonica, 47, 1-2, 1-75.

Baluk, W. (2003). Middle Miocene (Badenian) gastropods from Korytnica, Poland, Part IV. - Turridae. - Acta Geologica Polonica, 53, 1, 29-78.

Baluk, W. (2006). Middle Miocene (Badenian) gastropods from Korytnica, Poland, Part V. Addenda et Corrigenda ad Prosobranchia. - Acta Geologica Polonica, 56, 2, 177-220.

Garilli, V. (2011). Mediterranean Quaternary interglacial molluscan assemblages: Palaeobiogeographical and palaeoceanographical responses to climate chase. - Palaeogeography, Palaeoclimatology, Palaeoecology, 312, 1, 98-114. https://doi.org/10.1016/j. palaeo.2011.09.012

Harzhauser, M., Landau, B. (2016). A revision of the Neogene Conidae and Conorbidae (Gastropoda) of the Paratethys Sea. Zootaxa, 4210, 1, 1-178. https://doi.org/10.11646/zootaxa.4210.1.1

Høisæter, T. (2009). Distribution of marine, benthic, shell bearing gastropods along the Norwegian coast. - Fauna norvegica, 28, 1, 5-106. https://doi.org/10.5324/fn.v28i0.563

Hörnes, M. (1870). Die Fossilen Mollusken des Tertiær-Beckens von Wien. - Abhandlungen der Geologischen Bundesanstalt. Wien. $653 \mathrm{~s}$.

Hrabovský, J. (2009). Revízia červených rias (Rhodophyta) vybraných lokalít bádenu Moravy. - MS, diplomová práce. Př́rodovědecká fakulta Masarykovy univerzity. Brno.

Chira, C., Voia, I. (2001). Middle Miocene (Badenian) Conidae from Lapugy de Sus, Romania: systematical and paleoecological data. - Studia Universitatis Babes-Bolyai, 46, 2, 151-160. https://doi.org/10.5038/1937-8602.46.2.13

Jüttner, K. (1933). Der Kienberg und der Muschelberg. - Heimatblatt für Nikolsburger Bezirk, 9, 1, 75-78.

Kowalke, T., Harzhauser, M. (2004). Early ontogeny and palaeoecology of the Mid-Miocene Rissoid Gastropods of the Central Paratethys. - Acta Palaeontologica Polonica, 49, 1, 111-134.

Latal, Ch., Piller, W. E., Harzhauser M. (2006). Small-scaled environmental changes: indications from stable isotopes of gastropods (Early Miocene, Korneuburg Basin, Austria). - International Journal Earth Sciences (Geologische Rundschau), 95, 1, 95-106. https://doi.org/10.1007/s00531-005-0510-3

Mandic, O., Harzhauser, M., Spezzaferri, S., Zuschin, M. (2002). The paleoenvironment of an early Middle Miocene Paratethys sequence in NE Austria with special emphasis on paleoecology of mollusks and foraminifera. - Geobios, 35, 1, 193-206. https://doi.org/10.1016/S0016-6995(02)00059-1

Meric, E., Avsar, N., Nazik, A., Barut, I. F., Bergin, F., Balkis, N., Öncel M. S., Kapan-Yesilyurt, S. (2010). The response of benthic foraminifer, ostracod and mollusc assemblages to environmental conditions: a case study from the Camalti Saltpan (Izmir-Western Turkey). - Mediterranean Marine Science, 11, 1, 5-32. https://doi.org/10.12681/mms.88

Osvaldová, E. (2011). Paleontologické zpracování lokality Mušlov. - materiál ze sbírek Ústavu geologických věd. - MS, bakalářská práce. Př́rodovědecká fakulta Masarykovy univerzity. Brno.

Pisera, A. (1985). Paleoecology and lithogenesis of the Middle Miocene (Badenian) algal-vermetid reefs from the Roztocze Hills, south-easter Poland. - Acta Geologica Polonica, 35, 1-2, 89-155.

Procházková, O. (1981). Biostratigrafické postavení lokality Mušlov v neogénu Moravy. - MS, diplomová práce. Př́rodovědecká fakulta Univerzity Jana Evangelisty Purkyně. Brno.

Rundic, L., Kneževic, S., Rakijaš, M. (2013). Middle Miocene Badenian transgression: new evidences from the Vrdnik Coal Basin (Fruška Gora Mt., northern Serbia). - Annales Geologiques de la Peninsule Balkanique, 74, 1, 9-23.

Russo, R. (2017). Lagoon malacofauna: results of malacological research in the Venice Lagoon. - Bollettino malacologico, 53, 1, 49-62.

Seitl, L. (1981). Měkkýší fauna lokality Borač. - Časopis Moravského muzea, 66, 1, 33-50.

Tomanová Petrová, P., Turek, T. (2016). Kapitola 5. Mušlov. - In: Tomanová Petrová, P. (ed.): Molasse Meeting 2016 \& 18th Conference on Upper Tertiary, Excursion Guide, 34-41. Masarykova Univerzita, Ústav geologických věd.

Turek, T. (2016). Současný stav a paleontologie neogenní lokality Mušlov. - MS, bakalářská práce. Př́rodovědecká fakulta Masarykovy univerzity. Brno.

Výmolová, B. (2012). Oichnus paraboloides Bromley na schránkách miocenních měkkýšů z lokality Mikulov. - MS, bakalářská práce. Přírodovědecká fakulta Univerzity Palackého. Olomouc.

Zuschin, M., Harzhauser, M., Mandic, O. (2007). The stratigraphic and sedimentologic framework of fine-scale faunal replacement in the Middle Miocene of the Vienna Basin (Austria). - Palaios, 22, 1, 285-295. https://doi.org/10.2110/palo.2005.p05-023r. 